Gómez, M.S. (2017). El fundamento teológico político de la justicia premial en Thomas Hobbes. Revista de Sociología y Antropología: VIRAJES, 19 (1), 63-80. DOI: 10.17151/rasv.2017.19.1.4

\title{
EL FUNDAMENTO TEOLÓGICO POLÍTICO DE LA JUSTICIA PREMIAL EN THOMAS HOBBES*
}

\section{MARÍA SOLEDAD GÓMEZ GUZMÁN**}

Recibido: 11 de Diciembre de 2016

Aprobado: 15 de Febrero de 2017

Artículo de Reflexión

\footnotetext{
* El presente texto se circunscribe como artículo de reflexión, presentado en el I Foro nacional de estudiantes de derecho y ciencias políticas: Alteridad y reconocimiento, celebrado en el mes de septiembre de 2014 en la Universidad Pontificia Bolivariana, Medellín.

(1) ORCID: 0000-0002-3669-9541
} 


\title{
Resumen
}

Objetivo. Analizar el fundaamento teológico político de la justicia premial desde la teoría del Estado moderno de Thomas Hobbes, remitiéndose al sistema penal colombiano, para ejemplificar la vigencia de dicha teoría. Metodología. Se desarrollará el carácter político del discurso teológico, exponiendo la secularización de algunos conceptos. Se abordarán las potestades de la soberanía instituidas por la transferencia que cada individuo realiza al soberano, pudiendo castigar y perdonar la trasgresión a las leyes civiles. Se tratará el paradigma de la justicia premial, enfatizando su fundamento teológico político. Resultado. Se encuentra que la justicia premial propende por la conservación del orden jurídico institucional, encabezado por una autoridad superior que legitima cualquier actuación para dicha conservación. Conclusión. Así, la reconstrucción teológico política de la justicia premial sirve para entender un marco jurídico en el que soberano disponga de sus potestades, como la de perdonar las trasgresiones de quienes amenazan la existencia del Estado.

Palabras clave: Justicia premial, Estado moderno, teología política, secularización, soberanía.

\section{THEOLOGICAL-POLITICAL FOUNDATIONS OF PREMIAL JUSTICE IN THOMAS HOBBES}

\begin{abstract}
Objective: This article aims to analyze the political-theological foundations of premial justice from Thomas Hobbes, referring to the Colombian penal system, to exemplify the validity of the already stated theory. Methodology: The political nature of the theological discourse will be developed, exposing the secularization of some concepts. The powers of sovereignty instituted by the transference of powers that each individual transfers to the sovereign who can punish or forgive criminal offences, will be addressed. The paradigm of premial justice will be addressed with emphasis in its theological-political foundation. Results: It is found that premial justice tends to the conservation of the institutional legal order, headed by a superior authority that legitimates any action for such conservation. Conclusion: The theological-political reconstruction of premial justice serves to understand any legal frame in which the Sovereign has its powers as to forgive the transgressions of those who threaten the existence of the State.
\end{abstract}

Key words: Premial justice, modern state, political theological, secularization, sovereignty. 


\section{A modo de introducción}

bordar una reflexión en torno a la teología política de Thomas
Hobbes, como fundamento de la concepción del Estado
moderno, hace necesario el estudio antropológico que este suscita para la comprensión global de su teoría de Estado y de por qué esta es la única posible atendiendo a la naturaleza del hombre. Así, despejar esa totalidad-hombre-, circunscrita fatalmente al estado de naturaleza en un comienzo, hace ineludible la aparición de una autoridad superior, magnánima e irremplazable en la esfera de la asociación entre los hombres, que, por ese estado de naturaleza o guerra en el que se encuentran en principio inmersos, aunada a la naturaleza que le es propia por su condición, resultan enemigos unos de otros, conllevando a la intercepción de otro que representa su voluntad en aras de evitar la renovación de la guerra.

Por otra parte, legitimar un discurso como el teológico para enmarcar allí la construcción de un Estado y toda una teoría política que lo explique, no aparece de manera fortuita. Fruto del contexto político de su época, Hobbes a través de su construcción teórica, legitima otra fuente de autoridad diferente a la divina, $y$, por lo tanto, con fines distintos en cuanto a la determinación de la voluntad de los hombres. Era claro que, legitimar y obedecer a una fuente de autoridad distinta de la emanada de Dios omnipotente, deslegitimaba todo precepto devenido de cualquier otra. En consecuencia, la secularización de los conceptos propios de la teología hizo posible la construcción de un Estado cuyos atributos de poder pareciesen provenir de la misma fuente de la autoridad, permeando la esfera de las relaciones humanas y su vida en la tierra por el temor y el deber de obediencia a un Estado cuyo papel era igual al Dios, con el fin de conservar su existencia, siempre y cuando atendieran las ordenes de aquel a quien se había otorgado poder.

Sin embargo, la única manera en que el Estado reconociera y reconozca el papel de sus súbditos como obedientes de sus preceptos, es a través de la entrega de premios y recompensas, como formas de mantener la paz perpetua e identificar quién está en contra o a favor de las leyes del Estado. Es allí donde se edifica la fuerza y la perpetuidad de un orden civil en el cual, por temor al castigo y al despliegue de la fuerza incalculable del soberano, se cumplan las leyes y se cercena cualquier manifestación de rebeldía.

En suma, para vislumbrar de mejor manera los anteriores planteamientos, se toma como ejemplo la figura de la justicia premial, 'garantía' con la que cuentan los ciudadanos en el marco de un proceso penal en el ordenamiento jurídico colombiano, figura que sin duda alguna y luego de algunas consideraciones pertinentes, encuentra su fundamente en 
el marco de la teoría del Estado moderno, y por tanto en las construcciones teóricas de la teología política de Thomas Hobbes.

\section{Presupuestos antropológicos en la teología política de Thomas Hobbes}

"No hagáis a los demás lo que no quisieras que te hicieran a ti" o "todo lo que querríais hicieran los demás por vosotros, hacedlo vosotros por ellos" (Hobbes, 1979, p. 252). Iniciar con esta máxima, hace que la aproximación frente a la concepción del hombre en Hobbes, cuya condición natural es la guerra de todos contra todos y de la cual se desprenden sus fundamentos acerca del Estado moderno, se vislumbre de manera global, pues con esta ley permite examinar las demás leyes naturales, las cuales conciernen a la doctrina de la concepción hobbesiana del Estado civil. Pero, como ha de suponerse, para que se instituyeran dichas leyes, antecedió una necesidad en aras de establecer la paz (orden), como un mandato prescrito en la primera ley de la naturaleza. Dicha necesidad de concordia entre los hombres se instituye en virtud del estado de guerra o de naturaleza que precede la constitución del Estado.

Pero, ¿Por qué el hombre se encuentra inmerso primero en un estado de guerra? Según Hobbes, la naturaleza ha hecho a los hombres tan iguales en sus facultades mentales y corporales, como en sus deseos respecto a las mismas cosas y, por supuesto, en los medios para obtenerlos. Cada hombre en el estado de naturaleza posee, por las mismas razones lógicas, la esperanza de alcanzar sus fines a través de los medios que la naturaleza les provee. De manera que, si dos o más hombres pretenden lo mismo y no pueden ambos gozar de la misma cosa, se convierten en rivales o enemigos $\mathrm{y}$, por consiguiente, se lanza a la guerra y la destrucción en aras de la conservación frente a la inseguridad mutua. Los hombres se disponen a la guerra por el orgullo, esto es, por el deseo de ser reconocidos: "Cada uno se encuentra en la búsqueda de una más alta valoración” (Hobbes, 1979, p. 227). De aquí se desprenden pues las tres causas principales del estado de guerra: competición, inseguridad y gloria, las cuales constituyen la violencia y la guerra constante entre los hombres. En Hobbes, sin embargo, la guerra no implica necesariamente el combate directo y el derramamiento de sangre, sino la sensación de inseguridad: "la guerra es un espacio de tiempo donde la voluntad de disputa es suficientemente conocida por todos, la cual habría de existir siempre que no hubiese un poder común que obligara el respeto" (Hobbes, 1979, p. 227).

En Hobbes, los deseos y las pasiones que gobiernan al hombre - que no es otra cosa que una parte de esa totalidad llamada hombre, compuesta 
por el aspecto carnal, síquico o animal y espiritual, según la tricotomía antropológica a la que aludió San Agustín ${ }^{1}$ - no son en sí mismos pecado y tampoco las acciones procedentes de éstas, puesto que en el estado de naturaleza no existe ley ni autoridad civil. Cada uno está gobernado por su instinto de conservación y voluntad de poder. En efecto, hasta que los hombres conocen una ley, emitida por una autoridad representativa del orden, que les prohíbe ciertas acciones, se configura el delito (Hobbes, 1979, p. 227). Asimismo, en el estado de guerra no hay injusticias - puesto que en virtud de la conservación sólo la fuerza y el fraude se hacen presentes como las dos virtudes cardinales - ya que éstas sólo se hacen presentes en aquel lugar donde haya un poder común: Porque donde no hay poder común, no hay ley y donde no hay ley, no hay injusticias, es decir, donde no existe sociedad civil (Hobbes, 1979, p. 227).

Bajo este panorama desolador, sin embargo, el hombre encuentra la posibilidad de salir de la inseguridad y la desconfianza que le genera el otro, esto es, el prójimo, en parte por sus pasiones, en parte por su razón. En la primera se encuentran el temor de la muerte y el deseo de cosas necesarias para una vida confortable, y en la segunda, ésta sugiere artificios para lograr la paz, a lo que se le atribuye el nombre de leyes de la naturaleza. Es preciso aclarar que estas posibilidades y, sobre todo, aquella que proviene de la razón humana, generan como resultado la creación de la sociedad civil que se rige bajo una autoridad común.

Las leyes de naturaleza como mandatos de la razón son distintas al derecho natural, esto es, al derecho de todo hombre sobre todo, en tanto no existe impedimento alguno para disponer de la vida y las posesiones de los demás. De esta manera, y tal como se había mencionado, surge la ley fundamental de la naturaleza, la cual consiste en que el hombre debe esforzarse por la paz: "Buscar la paz y seguirla" (Hobbes, 1979, p. 229). Esto significa, sin embargo, que la guerra es la condición sine qua non de la paz, porque el soberano necesita la confrontación bien sea para crear su poder, bien sea para conservar el poder sobre la comunidad política. De la primera ley de la naturaleza, se sigue la renuncia que el hombre hace de su derecho a todo con miras a constituir el orden civil para la organización de las leyes y las armas. En otras palabras, renunciar al derecho de naturaleza, o derecho primero, implica que cada hombre se despoje de la libertad que posee para resistirse a otro hombre que en adelante monopoliza la fuerza.

El derecho de resistencia queda, entonces, proscrito en el estado civil. En este orden de ideas, y en lo concerniente a la renuncia de esta libertad natural, cabe igualmente la posibilidad de la transferencia común del

\footnotetext{
${ }^{1}$ San Agustín, 2007, p. 970
} 
poder a una persona determinada o a una asamblea de hombres, sin opción alguna de impedir que dicha persona representativa se beneficie de dicha transferencia de modo absoluto, porque deshacer voluntariamente dicho pacto por parte de los asociados es igual a injusticia. Esta renuncia recíproca atiende, pues, al mandato de la segunda ley de naturaleza:

Que un hombre está dispuesto tanto como él a renunciar a su derecho a toda cosa en pro de la paz y defensa propia que considere necesaria y se contente con tanta libertad contra otros hombres como consentiría a otros hombres contra él mismo. (Hobbes, 1979, p. 229)

Esa transferencia voluntaria por parte de todos respecto a un individuo determinado, es lo que los hombres llaman $p a c t o^{2}$. Así se llega a la tercera ley de la naturaleza, en la cual los hombres deben cumplir los pactos que han celebrado para no retornar a la condición de guerra e incurrir en injusticias dentro del orden civil. Los hombres con el pacto aceptan la creación de la sociedad y la justicia, ligados a un poder coercitivo que obliga igualitariamente a todos los asociados a cumplirlo pactado por el miedo al castigo que siempre será mayor respecto del beneficio de la ruptura del pacto.

Con todo, no existe tal poder antes de que erija una república civil. Igualmente, Hobbes alude a otras leyes de la naturaleza, como la gratitud para la conciliación de un hombre con otro; la deferencia, como el esfuerzo por acomodarse al resto de los hombres y de no querer hacerlo o abstenerse por la orden de sus pasiones, debe ser expulsado de la sociedad, por hallarse culpable de la guerra por venir y entorpecer la primera ley. También la ley del perdón para otorgar así mismo la paz; la de la venganza de los hombres por el respeto del bien por venir, entre otras, cuya violación no hacen más que poner en peligro el orden civil bajo un poder de organización común. Podría decirse, igualmente, que el quebrantamiento de las leyes de la naturaleza por parte de los individuos obedece al imperio de las pasiones y a la voluntad de guerra y batalla que antecedió a las disposiciones civiles.

En suma, el precepto que da lugar a discernir, por decirlo de alguna forma, la transición del estado de guerra, inminente e inherente al hombre frente a la ausencia de leyes, a una sociedad civil producto del pacto hecho con una persona determinada con miras a la emanación de los mandatos sociales, no es otro que la máxima de "No hagas a los demás lo que no

\footnotetext{
${ }^{2}$ La transferencia mutua de un deseo es lo que los hombres llaman contrato. También puede uno de los contratantes entregar por su parte la cosa contratada, y dejar que el otro cumpla con la suya en algún tiempo posterior determinado, confiando mientras tanto en él, y entonces el contrato por su parte se llama pacto o convenio (Hobbes, 1979, p. 231).
} 
quisieras que te hicieran a ti", siendo criterio indispensable para no retornar a la lucha de todos contra todos y respetar el orden consolidado, a fin de que no se deleiten mutuamente con la torpeza del placer ilícito (Hobbes, 1979, p. 252).

\section{Fundamentos de la teología política de Thomas Hobbes}

Abordar la teología política de Thomas Hobbes, en aras de comprender su planteamiento acerca de los orígenes del Estado moderno, pone de relieve la necesidad de explicar qué se entiende por tal concepto, con miras a encontrar los fundamentos del mismo, el cual transita obligatoriamente por el carácter político del discurso teológico de su época y del suyo propio, haciendo notar el proceso de secularización de las concepciones religiosas y de algunas nociones, tales como: Estado y autoridad. Hobbes utiliza la analogía entre Dios como creador del orden universal y el Estado como un dios mortal y creador de las condiciones pacíficas. "Non est potestas super terram quae comparetur ei" - "No hay poder en la tierra que se compare con el suyo" (Hobbes, 1979, p. 394). Comenzar con esta frase implica un intento por reunir y dilucidar el poder y la magnitud que atribuye el autor inglés a su concepción del Estado-Leviatán.

El Leviatán alude a algo más que una mera ficción teórica, ya que es el producto de un contexto histórico en Inglaterra a mediados del siglo XVII. Esta nación se encontraba sumergida en una convulsa confrontación religiosa y social, la cual estaba representada en una guerra civil contundente, donde los opositores se dividían en monárquicos y parlamentarios. Dicha guerra vive tres periodos distintos, en los cuales se destaca la decapitación del monarca Carlos I Estuardo en 1649, dando paso a la primera y única república inglesa de la historia encabezada por Oliver Cromwell, quien dirigió la república hasta 1661. Luego, con el triunfo del parlamento sobre el monarca, se estableció en Inglaterra una moral puritana que buscaba el afianzamiento del capitalismo, el cual constituía una forma de progreso social apoyado por la burguesía. Durante la dictadura de Cromwell, empero, la intransigencia frente a los católicos ingleses fue considerable al punto de llegar casi a su disolución completa: se instauró también un sistema basado en el orden público, apoyado por las constantes victorias sobre Holanda y España y la firma de la paz con Francia. Al morir Cromwell en 1658 y sin dejar sucesor alguno, la monarquía Estuardo se restaura en el trono dos años más tarde, que sería destronada en 1668 por la Casa Orange, el despotismo y el catolicismo constante. Durante este periodo, Hobbes mantuvo una posición intermedia, puesto que defendía la figura del Rey, pero sostenía que su poder no era de origen divino. A partir de estos hechos sumados a sus 
antecedentes filosóficos, Hobbes elaboró el Leviatán en el cual recoge toda su teoría acerca del contrato social, que señala el nivel y el funcionamiento de la sociedad en virtud de un pacto entre las partes afectadas, es decir, entre gobernantes -Rey, tradicionalmente- y los gobernados.

A partir de la idea que Hobbes tiene sobre el hombre y las atribuciones que por naturaleza le son propias - dominio de las pasiones -, el autor dilucida la necesidad de un pacto entre los mismos hombres, esto es, de un compromiso entre los individuos para renunciar al estado de guerra, el cual suscita la sensación de inseguridad continúa. Según Dalmacio Negro, al surgir la sociedad civil, a través de lo que puede traducirse también en términos de contrato, aparece el fundamento teológico político de la constitución de lo público, que, desde la modernidad, se instala como una promesa de conveniencia mutua que trasciende los intereses particulares (Negro, 1996, p. 16). Sin embargo, Hobbes señala que el poder político o común pertenece originariamente al pueblo, no como cuerpo, sino como conjunto de individuos, de fieles. Esta afirmación encuentra su fundamento en la Edad Media, a partir de Santo Tomás, quien distinguía entre la Iglesia como agrupación de creyentes y lo político como unión de hombres. En la modernidad, el Estado es, sin embargo, la consolidación de ambas calidades a partir de un solo pacto, únicamente ciudadanos y no fieles ${ }^{3}$.

De ahí que la idea hobbesiana de pacto que funda el Estado, hace que todo el pensamiento político moderno se circunscriba a la esfera de las nociones teológicas secularizadas, reduciendo la razón eclesiástica a la razón de Estado. De esta manera, se secularizan los conceptos teológicos, pasando a ser conceptos políticos. Conservar la teoría del contrato social, la que justifica toda la construcción del Estado a la luz de la teoría de Hobbes, pone de presente la teología como instrumento de persuasión indispensable para la existencia y supervivencia del orden político bajo el contexto moderno, ya que en el estado de naturaleza el miedo a Dios daba respaldo a los contratos. Por consiguiente, Hobbes pone al soberano como un Dios todo poderoso, el cual debe tener un poder absoluto para que los hombres en el Estado y respecto al soberano padezcan un terror semejante al que le deben a Dios omnipotente. El dios mortal debe ser obedecido incondicionalmente por los súbditos, ya que de dicha sujeción depende la seguridad del orden y de la vida de los asociados.

\footnotetext{
${ }^{3}$ Todo esto lleva pues a afirmar que el contrato moderno es una noción teológica política donde se instaura lo público y no lo jurídico privado como en el Medioevo, el cual era sellado con un juramento, prenda de la buena fe de las partes, teniendo a Dios como testigo del mismo. En el contexto de la modernidad el juramento ante Dios, no añade nada a la obligación política de cumplir la promesa-pacto entre los mismos hombres, puesto que si es legal, obliga de igual manera ante los ojos del Creador con o sin el juramento, pero, por el contrario, si es ilegal no produce efecto alguno ni obliga en absoluto, así este se encuentre precedido por dicho juramento (Negro, 1996, p. 244).
} 
En efecto, el autor inglés recalca la importancia de la paz y la seguridad dentro del orden político, bajo la certeza de que el mayor peligro para la república subyace en el hecho de que los súbditos deban obedecer a leyes emanadas de diferentes maestros. Con esto, Hobbes asevera la necesidad de un poder absoluto, es decir, de un poder del cual emanan los castigos frente a los cuales no quepa la más mínima duda de obediencia. Por eso, al parecer, para la subsistencia del Estado Moderno a través de la secularización de conceptos teológicos o, lo que es lo mismo, la desteologización de los mismos, emergen nociones transversales a toda su teoría, por ejemplo, la noción de Estado-Leviatán (Dios). Hobbes se sirvió de la teología para instaurar una voluntad arbitraria que decide libremente sobre las leyes, esto es, como un Dios mortal que provee la seguridad y la paz en el estado civil, evitando el retorno al estado de guerra tal como lo exige el soberano.

En Hobbes aparecen, además, dos nociones importantes: reino de Dios y salvación, ambos desentrañados y aplicados al orden político por la interpretación que el autor inglés hace de las escrituras sagradas, definidas por él como un artificio humano susceptible de exégesis (Negretto, 2002, p.119). Frente a la definición de lo que se concibe como Reino de Dios encontramos varios elementos en Hobbes: El primero, alude a su definición como un reino terrestre- equivalente a la ciudad de Dios en San Agustín, que existió en el pasado y que no será restaurado sino hasta el regreso de Cristo, en el cual no hay salvación ni inmortalidad, sino hasta el fin de la historia. Por ello, afirma el filósofo inglés, que dicha interpretación corresponde al poder supremo del Estado, ya que en las Escrituras no evidencia que el alma humana sea eterna y que los premios y los castigos sea literales, quedándole al hombre como contexto de salvación su presente terrenal. Lo segundo que se manifiesta es la relación que tienen los castigos y las recompensas frente a la salvación que se puede otorgar dentro del orden civil fruto de un pacto, puesto que de estos depende la redención por parte del soberano fruto del temor que suscita la desobediencia, en tanto el lenguaje del miedo trae consigo la imagen de omnipotencia que debe tener aquel que gobierna, imagen cuasi-divina, cuyo único camino de evitar tanto poder es la obediencia de las leyes civiles. Justamente, la sumisión frente al soberano es producto de la esperanza de salvación en la tierra, la cual enlaza con la salvación eterna, en tanto se cumplan las leyes civiles.

Una vez instituido el poder político sobre el religioso debido al temor a un castigo atroz, se afirma una soberanía absoluta e incuestionable que incluye todo ámbito religioso convirtiendo la razón privada en pública, es decir, que el juicio sobre el bien y el mal corresponde únicamente a la ley civil. El tratamiento de la religión a partir de un carácter político evita 
retroceder a un contexto de guerra, en tanto si de cada autoridad surgiera una ley propia conllevaría a la aniquilación del Estado, residiendo en la fundación del Estado Moderno una respuesta a la necesidad de una única fuente de autoridad. Por ende, la teología política moderna es la mediadora en la tensión lógica entre las dos ciudades agustinianas: la ciudad de Dios equivalente a un estado de paz y la civitas diaboli semejante a un estado de guerra, ya que a partir de la trasfiguración de la imagen de reino de Dios en la tierra, en la de un estado de paz integrador de lo político y religioso, garantiza con su orden y seguridad la salvación de este mundo ${ }^{4}$.

Hobbes no niega, sin embargo, la vida eterna como tal, sino que la pone al margen de la historia presente. En efecto, el autor inglés manifiesta un desconocimiento de la verdad religiosa y de lo dicho por Dios, lo que le permite afirmar la única verdad que está a disposición de la voluntad del soberano, donde para conocer a Dios se requiere de la autoridad política a partir de la sustracción de sacralidades religiosas. El escepticismo que radica en el autor frente a un orden natural introduce la sustitución de éste por otro artificial aquende, supeditado al poder humano. En suma, la idea misma de soberanía-reconocimiento que el pueblo hace a algunos hombres del derecho de mandar y de decidir sobre la vida y la muerte, a través de un pacto- es el eje del poder del Estado Leviatán, en el que debe existir una sumisión absoluta por el desconocimiento a lo mandado por Dios, siendo la afirmación anterior el núcleo de la secularización moderna.

Por medio de las interpretaciones bíblicas, Hobbes ataca la superstición de los hombres, desplazando a Dios de la historia, poniendo la salvación eterna en términos temporales para justificar la obediencia que se le debe al soberano, quien es el único responsable de afirmar lo dicho por las escrituras. Aquí se hace visible el mensaje hobbesiano para justificar cualquier actuación de poder en pro de la vida, la seguridad y la salvación. De ahí el mismo nombre Leviatán, cuyo origen es teológico en principio y, a partir de Hobbes, un concepto secularizado, puesto que este monstruo bíblico tiene un poder comparable con el de Dios, no existiendo poder en la tierra comparable con el suyo (Job 41;33-34). Así existe un Dios ausente y un soberano presente para garantizar la seguridad y la paz de los ciudadanos.

\footnotetext{
4 "La naturaleza (cuyo orgullo y otras pasiones se han forzado a someterse al gobierno), junto con el gran poder de su gobernante, a quien compararé con el Leviatán [...] Nada hay, dice, sobre la tierra comparable con él. Está hecho para no sentir miedo. Ve toda cosa por debajo de él y es rey de todos los hijos del orgullo" (Hobbes, 1979, p. 394).
} 


\section{De las penas y las recompensas: potestades de la soberanía}

Fruto del terror de los súbditos, el cual deviene de la transgresión a la ley civil, hace que los castigos y las recompensas por el incumplimiento o no del mandato soberano, se conviertan en los nervios y tendones por los cuales se mueven los miembros dentro de una república. Como ya se había mencionado, la utilización de ciertos conceptos teológicos tales como salvación y redención, entre otros, ponen de presente la necesidad de los súbditos por buscar el perdón y la misericordia de aquel que tiene un poder comparable con el de Dios, esto es, el Leviatán, quien tiene la facultad delegada por el Ser supremo de castigar y apartar a cualquiera de una vida eterna, para la cual se necesita de la salvación en la vida temporal, aquella que solo se logra mediante la sumisión y la obediencia al dios mortal.

“La pena o castigo dentro del Estado moderno, puede definirse como un mal infligido por la autoridad pública a quien ha hecho u omitido lo que la misma autoridad concibió como una trasgresión a la ley" (Hobbes, 1979, p. 386). Esto significa que el terror que proviene de la pena por el mal venidero, hace que los hombres obedezcan lo establecido, es decir, lo instituido por el poder y la fortaleza que se le otorga a un hombre o asamblea de ellos, los cuales poseen todas las voluntades reunidas bajo su autoridad. Entonces, la conformación de ese Estado, traducido como la multitud de hombres que pactan cada uno con cada uno que a cierto hombre le será otorgado por mayoría el derecho a representar a la persona de todos $\mathrm{y}$, aunque existan quienes estén en contra, aun así, deben autorizar todas las acciones y juicios que ese hombre haga como si fueran los suyos propios, entre ellos, las penas establecidas y ejecutadas bajo su poder (Altini, 2005, p. 92).

Sin embargo, del producto de ese pacto, no puede concluirse que los asociados le entregaron a la autoridad el derecho a poner violentamente las manos sobre su persona, ni tampoco deriva de la concesión, la posibilidad de no resistir a la violencia (Hobbes, 1979, p. 386). Al nacer pues una república, todo hombre abandona el derecho de defender a otro hombre, pero no el de defenderse a sí mismo; igualmente se obliga a asistir a quien tiene la soberanía en el hecho de castigar a otro, pero no a sí mismo. En este orden de ideas, el derecho exclusivo del soberano a castigar no se funda sobre ninguna donación de los súbditos, tanto así, que antes de consolidarse dicho poder común, los individuos tenían derecho a todo y a hacer lo que considerasen necesario para la preservación de su propia vida respecto, por ejemplo a matar, herir, someter, etc., encontrando aquí el fundamento del derecho a penar: al no concedérselo directamente al soberano, al renunciar al suyo, lo fortalecieron para que usase el propio poder como considerara 
conveniente para la preservación de todos. En otras palabras, en pro de la república y su consolidación absoluta, al desistir del derecho que cada uno tenía frente a otro y frente a todo, se robustecen las potestades del soberano con miras a no retornar a la sensación de guerra continúa. Así, cada uno es autor del actuar del soberano, siendo este un representante ${ }^{5}$ ilimitado, cuyos actos de autoridad deben entenderse bajo la idea de sumisión o acatamiento de todas las voluntades a la del soberano, esto es, a todas las acciones representativas. Dichas acciones son pues, potestativas de un representante que legitiman los asociados y, adicionalmente, obligan a los sujetos que sin ello no existen y que solo aquello es capaz de personificarlos, es decir, la voluntad del soberano es autonomizada ${ }^{6}$ en forma personalista como artificio, dotado de razón y voluntad, en el cual confluye la unión de todos en una sola y la misma persona ${ }^{7}$. Por lo tanto, al Leviatán, ese dios mortal al que se le debe la paz y la defensa, se le atribuye la esencia del Estado: una persona única constituida por una gran multitud mediante los pactos recíprocos de todos sus miembros, con el fin de que esa misma persona pueda emplear la fuerza y los medios de todos como los juzgue convenientes para asegurar el objetivo que justifica toda la construcción del Estado moderno, es decir, la paz y la defensa común, poniendo freno a todos los orgullosos a través del poder y el miedo.

Siguiendo así con la potestad de imponer penas para castigar la trasgresión a la ley emanada del soberano, es importante establecer que los castigos no pueden ser de cualquier forma y, en ese sentido, deben contar con características impetradas por él mismo. En primer lugar, las venganzas privadas de los hombres particulares, no pueden ser consideradas como tal, ya que estas no proceden de la autoridad pública, quien ostenta el monopolio del poder. Tampoco ningún hombre puede ser despreciado públicamente, ya que no puede atribuirse un nuevo mal en comparación con las acciones ya realizadas. En segundo lugar, para que un mal sea considerado como pena, debe ser antes juzgado como trasgresión de la ley por parte de quien ostente el poder. Esto resulta claro a la luz de los planteamientos de la teología política de Hobbes ya que la trasgresión, es decir la ofensa, no se reputa contra los individuos de la comunidad, sino contra el Estado y, por supuesto, contra quien detenta el poder de las leyes. Asimismo, toda pena establecida debe tener como fin el hecho de que los hombres obedezcan la

\footnotetext{
${ }^{5}$ La representación pone de presente aquello que está ausente o da forma a aquello que por naturaleza es informe.

${ }^{6}$ Con este término me referiré a que la unión de las voluntades que producen el pacto, hace que las acciones emanadas sean autónomas, es decir, no dependientes de la voluntad de los mismos súbditos. ${ }^{7}$ Persona es aquella cuyas palabras o acciones son consideradas como suyas propias o como representación de palabras o acciones de otros hombres, o de alguna cosa a la cual son atribuidas ya sea como verdad o ficción
} 
ley y, asimismo, que no se obtengan ningún producto de la desobediencia, es decir, que la pena, a pesar que sea mínima, siempre debe generar temor. En igual sentido, para que la pena constituya un verdadero castigo, debe estar completamente determinada, al igual que el hecho cometido debe estar prohibido anteriormente por la ley, puesto que antes de esta no puede haber violación de la ley civil (Hobbes, 1979, p. 387).

Igualmente, el mal cometido sobre la persona que representa la república no es pena, sino un acto de hostilidad, ya que la pena debe ser ejecutada solo porla autoridad pública, y esta solorecae sobreel representante del Estado. Pero, el daño o mal que recae sobre los enemigos de la república no cabe bajo el nombre de pena, puesto que, si nunca estuvieron sometidos a la ley o dispuestos a cumplirla, no pueden transgredirla y los daños sobre su persona serían considerados como actos de hostilidad. Sin embargo, en guerra declarada, cualquier mal es legítimo o lo que es lo mismo, el daño causado a los súbditos rebelados se hace por derecho de guerra y no a modo de pena (Hobbes, 1979, p. 388). Si un súbdito pues, niega el poder emanado de la potestad del representante de hecho o palabra de manera intencional aunque hubiese pena establecida para la traición, puede legítimamente hacérsele sufrir lo que el soberano quiera, ya que negando el sometimiento, niega el castigo y debe sufrir como rival y a voluntad del representante, es decir que para perpetuar el poder del soberano de manera absoluta y así conservar la república, le es permitida y justificada cualquier acción, ya que es su función asegurar la seguridad y la paz, pudiendo ser el uso de la guerra y la violencia medios necesarios para ello.

En principio, si el castigo es la consecuencia que se sigue de la trasgresión a la ley civil, la pena impuesta al inocente se opone a la ley natural: antes que nada, se opone a aquella que prohíbe a los hombres perseguir en sus venganzas algo diferente del bien futuro, ya que algo opuesto a ese fin no puede significar un bien para la república. También sería opuesto a la gratitud que los súbditos esperan del soberano luego de otorgarle su poder, ya que dicha concesión se hace para que sean protegidos a cambio de obediencia y castigarlos sería devolver mal por bien. Pese a lo anterior, esto no significa en modo alguno que la ruptura de la ley de la naturaleza implique cualquier mal a un inocente que no sea súbdito, si esto significa beneficio para la república y tampoco acarrea la violación de un pacto anterior, ya que aquellos que no sean súbditos son o bien enemigos de la república o personas que han dejado de obedecer por algún acto procedente. En ese sentido, es legítimo por el derecho original de naturaleza hacer guerra contra los disidentes que el soberano considere capaces de causar perjuicio, es decir, los rebeldes, aquellos que han negado deliberadamente la autoridad pública, renunciando al sometimiento, deben 
sufrir también como enemigos, porque la rebelión no es sino la guerra renovada.

Si bien en la república existen castigos por la transgresión a la ley civil, también se establecen las recompensas, que provienen de un regalo o contrato, y que en este último caso se denominan salario, los cuales son beneficios por un servicio realizado. Empero, aquellas que provienen de la primera fuente, son procedentes de la gracia de quien los otorga, es decir, del soberano, para estimular o permitir a los hombres hacerles algún servicio (Hobbes, 1979, p. 393), obligados por el honor al agradecimiento y a un propósito de restitución, el cual puede ser servir siempre al público y obedecer siempre a la autoridad. No obstante, en el caso de que uno u otro beneficio sea concedido a un súbdito por miedo a un poder o habilidad que posee este último para causar daño a la república, no son exactamente recompensas, ya que no existe contrato para que del mismo se derive por ejemplo un salario, porque cada individuo está obligado de antemano a servir al Estado; y tampoco se derivaría de la gracia por ser extraídos por miedo, el cual se supone no debería afectar el poder soberano. Entonces, serían más bien sacrificios que el representante hace para calmar la inconformidad de aquel a quien considera más poderoso que él mismo (Hobbes, 1979, p. 393).

Por tanto, si el fin último del Estado-Leviatán es ser absoluto en su poder, no existiendo otra potencia que le contradiga, los castigos y las recompensas se tornan como base fundamental para lograr el cumplimiento y el respeto por las leyes civiles, las cuales legitiman el poder del soberano, ya que están hechas a su imagen y semejanza, en aras de conservar el Estado, la paz y la seguridad, utilizando cualquier medio que considere necesario para no retornar a la condición de guerra, así sea esta última un derecho que el representante pueda conservar para garantizar los fines de la república. Con todo, si en el soberano confluye cuanta potencia se pueda vislumbrar en la tierra, este es el único con la potestad de hacer que los hombres se sometan a su dominio a través del terror que se infunde por el castigo, también, al mismo tiempo, el único capaz de tener misericordia con aquellos que han trasgredido la ley, pero no han dejado de ser súbditos, y de premiar a los que han obedecido sin reparar en su autoridad.

\section{La justicia premial en el sistema jurídico penal colombiano}

Producto de las potestades propias del soberano dentro de la república, resulta claro que los castigos y las recompensas son las articulaciones del Estado, ya que por medio de estas se logra o bien intimidar a los ciudadanos para que estos cumplan los mandatos de autoridad, o bien someter al 
agradecimiento y, a su vez, a un propósito de restitución frente a quien les otorgó el premio, puesto que el acto de compasión a su persona es equivalente a la misericordia divina que no puede sino retribuirse con la obediencia frente a sus preceptos absolutos. De ahí que castigar o premiar en el Estado-Leviatán es la única forma de doblegar a las masas para evitar la rebelión y perpetuar el poder.

Dentro del sistema jurídico penal colombiano, pueden vislumbrarse claramente figuras cuyo fundamento no es otro que el de mantener el Estado; es decir, el sistema cuenta con instituciones que no son más que instrumentos de intimidación para que los asociados no se rebelen contra el representante soberano, quien por el poder que le asiste fruto de la concesión de los ciudadanos, tiene la autoridad para establecer las leyes que deben ser obedecidas.

En el ámbito del proceso penal, específicamente, existe una figura que puede resultar de gran utilidad, para que la justicia sea mucho más eficaz y rápida, ya que su aplicación aumenta las cifras de condena o de individuos que por el temor que el castigo les genera se arrepienten y confiesan su trasgresión a la ley. Así, la búsqueda del perdón y por supuesto de un castigo menor, hace que los rebeldes estén de nuevo bajo la protección de la autoridad suprema. Entonces, para lograr una mayor aproximación a la figura procesal a la que se refiere el presente texto, es importante abordar su definición y orígenes, para luego establecer el fundamento teológico político, lográndose demostrar que no es otro diferente al que justificó toda la construcción de la teoría del Estado moderno de Hobbes.

La justicia premial como parte de la estructura del nuevo modelo procesal - ley 906 de 2004-, es una forma de justicia, que se basa en la idea de hacer uso de premios y castigos con diversos fines, en los que se encuentran los de estimular la confesión, delación y terminación anticipada del proceso. Esta forma de hacer justicia por parte del Estado, considera que es posible que a través de sus respectivas manifestaciones se llegue a un negocio que permita "ahorrarse el juicio" y elaborar un acuerdo que defina la responsabilidad penal (Manco López, 2012, p. 191). Uno de los instrumentos de los que se vale esta manifestación de justicia es la política de recompensas, la cual constituye una parte fundamental de la política criminal para combatir el delito, pudiendo, entre otras cosas, definir de manera previa al juicio la responsabilidad del imputado, renunciando a tal garantía para obtener rebajas de la pena que le corresponde por la colaboración o confesión de la culpabilidad.

Esta forma de hacer justicia en el procedimiento penal colombiano es tomada del sistema penal anglosajón, donde la figura de justicia premial -plea bargaining-, permite hacer una negociación entre la fiscalía y el 
imputado para obtener una confesión de culpabilidad a cambio de ciertas ventajas. En dicha institución existen ciertos elementos que la configuran: en primer lugar se encuentra la confesión de culpabilidad -guilty plea-, por medio de la cual el reo se declara conforme a los cargos que se le imputan y que además, toma tres formas básicas: una confesión voluntaria en el evento en que la culpabilidad sea notoria; otra estructuralmente inducida, cuando la ley prevé una pena más grave para quien insiste en el juicio, es decir, frente aquellos que niegan la verdad aducida por el Estado; y, por último, una negociada, en la que el acusado o su intermediario disponen con el ente acusador del delito o la pena. Así pues, la justicia premial propende por anular el juicio y deja al ciudadano a merced del fiscal y su poder (Manco López, 2012).

Así pues, bajo la misma lógica se desarrolla la justicia penal premial en Colombia, la cual consiste en una institución cuya esencia radica en la negociación de la pena y en la aceptación de culpabilidad del procesado ahorrándose, por ejemplo, la etapa del juicio, en aras de obtener una justicia más pronta y eficaz, que sacrifica una serie de garantías propias del sistema con tendencia acusatoria. Sin embargo, la justificación que se encuentra inmersa detrás de este tipo de justicia es la falta de legitimidad que estaba permeando el sistema, ya que la capacidad del Estado se veía menguada frente a una serie de situaciones que se desarrollaban socialmente, y para las cuales la comunidad exigía solución. Así, la justicia premial se tornó como un "mal necesario", donde el Estado renuncia a la obtención de la verdad material y al deber judicial del esclarecimiento de los hechos, por la eficiencia del sistema, existiendo una tajante desigualdad del acusado con respecto al poder del acusador público, es decir, en virtud de la fuerza de coacción estatal, sometiéndose el procesado por las rebajas -premios- o por la amenaza punitiva -castigos- independientemente de la inocencia o culpabilidad que le asiste, dejando atrás la esencia del procedimiento bajo una modalidad acusatoria: la contradicción y ser un sistema de partes.

Además, pueden percibirse objetivos distintos a los que públicamente caracterizan esta forma de hacer justicia. Existe pues, una 'atenuación' del poder punitivo en razón de la disminución de las penas imponibles, que no es otra cosa que el sometimiento a un poder mucho mayor al del procesado, por ser aquel capaz de premiar a cambio de sumisión a su autoridad. Por otro lado, el fin que puede entreverse de este tipo de justicia es el de asegurar un castigo sin juicio, con un propósito represivo o punitivo, ya que la negociación se hace fácil en tanto la pena pueda intimidar al 'delincuente'. Entonces, 
Las funciones no declaradas del sistema de premios y/o recompensas, pueden circunscribirse a la generación de un derecho penal expansionista, al servicio de causas foráneas que emplea de manera falaz un régimen de atenuación punitiva prometido para quien renuncia a la garantía del juicio, institucionalizando el engaño. (Castaño, 2013, p. 174)

Al mismo tiempo, la justicia premial se encarga de castigar doblemente al reo: por el delito y por su instancia en el juicio, o sea, oponerse al soberano significa una amenaza y un enfrentamiento a su poder magnánimo.

Del mismo modo el Estado, aparentemente, cede en su poder de soberanía, conservando igualmente su potestad para castigar o perdonar, actuando de acuerdo con sus intereses, por ejemplo, el de perpetuar su poder. A renglón seguido, la justicia penal premial obedece a una racionalidad económica instrumental que constriñe al reo, anula libertades, compra acusaciones y absoluciones, en otras palabras, una verdadera arma de autoritarismo penal, ya que la supuesta igualdad de la que gozan las partes que acuerdan la pena es una ficción que cubre las imposiciones de la parte más fuerte en la negociación, es decir, del Estado (Manco López, 2012, p. 210). Al procesado pues, se le presiona, instiga y constriñe mediante diferentes beneficios que advierten la conveniencia de acogerse a ellos, en comparación con el temor que genera el castigo si ha de inclinarse por la opción del juicio, para renunciar de manera voluntaria a los derechos y garantías que le asisten. Por eso, este tipo de justicia es un instrumento de eficiencia en el castigo, que pone a la persona en un estado de vulnerabilidad y miedo frente al sistema penal que, en vez de restringir el poder punitivo, lo amplifica.

\section{A modo de conclusión}

En consecuencia, la justicia premial se torna como un instrumento a través del cual el poder del soberano puede instituirse de manera absoluta, siendo este el único con la potestad de disponer del castigo que deviene de la pena, ya que al otorgar recompensas con el fin de que se sometan a su poder, igualmente constituye terror frente al mal venidero, es decir, de una manera u otra logra la intimidación de los coasociados para que obedezcan las leyes civiles en pro de asegurar la paz y permear de seguridad a aquellos que viven bajo un sometimiento fundado en el terror. También, la negociación del castigo del reo, no es otra cosa que una manifestación de la omnipotencia del Estado y una evidente constatación de que el mal que genera el incumplimiento de las ordenes, no son más que atentados directos 
contra su autoridad, puesto que el soberano es la verdadera víctima en la rebelión de los súbditos contra sus preceptos, y no aquel sobre quien recae directamente las consecuencias que genera el delito. Así, la única forma de salvación frente al poder del soberano, es el cumplimiento de lo prescrito por él, ya que fruto de sus potestades está en la capacidad de castigar y perdonar a los individuos para imponer su supremacía frente a cualquier fuente de la que puedan emanar otros designios. En suma, la desigualdad y el eficientismo que subyace bajo la figura de la justicia premial son correlativos al absolutismo propio de la teoría del Estado moderno esbozada por Hobbes, ya que no juega un sistema de partes, sino la imposición y el temor de alguien superior de quien emana la ley civil, sin respeto alguno de las garantías, con el objetivo único de legitimar cualquier actuación, ya sea la de perdonar o castigar como un dios mortal para salvarse de un mal desolador.

\section{Referencias bibliográficas}

Altini, C. (2005). La fábrica de la soberanía. Maquiavelo, Hobbes, Spinoza y otros modernos (Trad. C, Longhini \& S, Sánchez). Argentina: El Cuenco de Plata.

Castaño Vallejo, R. (2013). El sistema penal acusatorio en Colombia y el modelo de derecho penal premial. Análisis de las sentencias 36.502 de 2011 y 38.285 de 2012 de la Corte Suprema de Justicia y la sentencia C-645 de 2012 de la Corte Constitucional. Revista Nuevo Foro Penal, 9 (80), 165-185. Recuperado de http://publicaciones.eafit.edu.co/index. php/nuevo-foro-penal/article/view/2257/2187 (2016)

Garzón Vallejo, I. (2009). El triunfo del dios mortal. Una lectura hobbesiana de la secularización. Revista Enfoques: Ciencia Política y Administración Pública, VII (10) 67-90 Recuperado de http://www.redalyc.org/articulo.oa?id=96012388005 (2014)

Hobbes, T. (2005). Elementos de derecho natural y político. (D. Negro Pavón, trad.). Madrid, España: Península.

Hobbes, T. (1979). Leviatán. Ed. C. Moya \& A. Escohotado. Madrid: Editorial Nacional.

Manco López, Y. (2012). La verdad y la justicia premial en el proceso penal colombiano. Estudios de Derecho, Vol LXIX N¹53, junio 2012, 190-214.

Negretto, G. (2002). La política como teología secularizada. Una interpretación del Leviatán de Hobbes. Revista Internacional de Filosofía Politica, (20), 113-126. Recuperado de http:// dialnet.uniroja.es/servlet/articulo? codigo $=619412$

Negro Pavón, D. (1996). La teología política de Thomas Hobbes. Anales del Seminario de Historia de la Filosofía, 1, 229-261 Recuperado de http://dialnet.uniroja.es/servlet/ articulo?codigo $=2143819$

San Agustín. (2007). Obras completas. (Trad. Santos Santa Marta del Río y Miguel Fuertes Lanero). Madrid: Biblioteca de Autores Cristianos.

Schmitt, C. (1991a). El concepto de lo político (R. Agapito, trad.). Madrid, España: Alianza.

Schmitt, C. (2009). Teología política (F. Javier Conde y J. Navarro Pérez, trad.). Madrid, España: Trotta. 